\title{
Studi Komitmen Organisasi Karyawan Bank: Peran Job Involvement Dan Kepuasan Kerja
}

\author{
A.P. Sari, S.H. Senen \& M. Masharyono \\ Universitas Pendidikan Indonesia \\ ajengpurnamasari@student.upi.edu
}

\begin{abstract}
Employees who are committed to the organization have a tendency to continue working in the organization. The loss of employee commitment means organizations lose support and loyalty from employees in achieving organizational goals. One of the companies that experienced a decline in employee organizational commitment was X Bank. The purpose of this study is to determine how much influence job involvement and job satisfaction on organizational commitment. The object in this study was employees of $X$ bank, one of Indonesia's conventional banks. This study used saturated samples with 54 respondents. The data analysis technique used is Partial Least Squares (PLS) with computer software program smartPLS version 3.0. The results reveal that job involvement and job satisfaction influence organizational commitment. This shows that the higher job involvement and employee job satisfaction together, the higher the organizational commitment of X Bank employees.
\end{abstract}

\section{ABSTRAK}

Karyawan yang berkomitmen untuk organisasi memiliki kecenderungan untuk tetap bekerja dalam organisasi. Hilangnya komitmen karyawan berarti organisasi kehilangan dukungan dan loyalitas dari karyawan dalam mencapai tujuan organisasi. Salah satu perusahaan yang mengalami penurunan komitmen organisasi karyawan adalah Bank X.Tujuan dari penelitian ini adalah untuk mengetahui seberapa besar pengaruh job involvement dan kepuasan kerja terhadap komitmen organisasi. Objek dalam penelitian ini adalah karyawan bank X, salah satu bank konvensional Indonesia. Penelitian ini menggunakan sampel jenuh dengan berjumlah 54 responden. Teknik analisis data yang digunakan adalah Partial Least Squares (PLS) dengan alat bantu software komputer program smartPLS versi 3.0. Hasil penelitian menunjukkan bahwa job involvement dan kepuasan kerja berpengaruh terhadap komitmen organisasi. Hal ini menunjukkan bahwa semakin tinggi job involvement dan kepuasan kerja karyawan secara bersamasama, maka semakin tinggi juga komitmen organisasi karyawan Bank X.

\author{
ARTICLE INFO: \\ Article history: \\ Received 11 Februari 2019 \\ Revised 12 Februari 2019 \\ Accepted 13 Februari 2019 \\ Available online $24 \mathrm{Mei}$ \\ 2019
}

\section{Keywords:}

Bank; Job Involvement; Job

Satisfaction;

Organizational

Commitment

\author{
Kata Kunci: \\ Bank; Job Involvement; \\ Kepuasan Kerja; Komitmen \\ Organisasi
}




\section{PENDAHULUAN}

Aset terpenting dalam sebuah organisasi adalah sumber daya manusia karena sumber daya manusia berperan dalam mencapai tujuan organisasi (Senen et al., 2016). Sumber daya manusia sangat penting dalam menunjang organisasi melalui karya, bakat, kreativitas, dorongan dan peran nyata seperti yang dapat dilihat dalam setiap organisasi (Masharyono \& Senen, 2015:121). Perusahaan perlu memberikan pengarahan kepada karyawannya agar dapat membantu perusahaan dalam pencapaian tujuan yang telah direncanakan (Senen, 2016:42). Keberhasilan atau kegagalan dalam sebuah organisasi bergantung pada kompetensi karyawannya (Senen, Sumiyati, \& Masharyono, 2017). Organisasi harus menjaga karyawannya agar tetap memiliki kinerja yang baik dan memelihara karyawannya agar dapat mendedikasikan diri kepada organisasi tempat di mana karyawan bekerja (Masharyono, 2015:813).

Suatu organisasi agar dapat memilki keunggulan bersaing diperlukan komitmen karyawan yang terus-menerus kepada organisasi. (Kyoo \& Jeung, 2006). Karyawan yang berkomitmen untuk organisasi memiliki kecenderungan untuk tetap bekerja dalam organisasi dan menunjukkan perilaku yang baik (Allen \& Meyer, 1996) (Meyer, Paunonen, Gellatly, Goffin, \& Jackson, 1989). Banyak perusahaan yang menyadari pentingnya meningkatkan komitmen organisasi pada karyawan (Kyoo \& Jeung, 2006). Meningkatkan komitmen organisasi karyawan menjadi perhatian penting untuk mempertahankan karyawan yang berbakat dalam perusahaan (Neininger, Lehmannwillenbrock, Kauffeld, \& Henschel, 2010).

Konsep komitmen organisasi masih menjadi penelitian yang penting dalam bidang manajemen sumber daya manusia (MSDM) dan perilaku organisasi (Yi-Ching Chen, Shui Wang, \& Sun, 2012). Komitmen organisasi berpengaruh dalam mengubah perilaku karyawan (Lambert, 2003 dalam Crow, Lee, \& Joo, 2012). Banyak peneliti menemukan bahwa keberhasilan sebuah organisasi ditentukan oleh karyawan dengan memiliki komitmen organisasi yang tinggi (Jassawalla \& Sashittal, 2003; Brooks, 2002; McElroy, 2001 dalam Keskes, 2014). Penelitian terdahulu menemukan bahwa tingkat komitmen organisasi yang tinggi berkorelasi dengan pekerjaan yang berhubungan dengan perilaku dan sikap yang positif, termasuk perbaikan kinerja (Meyer et al., 1989 dalam Crow et al., 2012), keterbukaan untuk inovasi (Wycoff dan Skogan, 1994), produktifitas pekerja (Clegg dan Dunkerley,1980 dalam Crow et al., 2012), kepuasan pekerjaan (Meyer, Allen, \& Smith, 1993), dan tanggung jawab (Witt, 1990 dalam Crow et al., 2012), sementara tingkat komitmen organisasi yang rendah terkait dengan pekerjaan yang berhubungan dengan sikap dan perilaku yang negatif, (Bashaw dan Grand, 1994 dalam Crow et al., 2012), penyimpangan dari peraturan pekerjaan (Haarr, 1997 dalam Crow et al., 2012), dan ketidakhadiran karyawan (Farrell dan Stamm, 1988 dalam Crow et al., 2012).

Masalah komitmen organisasi terjadi pada beberapa industri seperti Usaha Kecil Menengah (UKM) (Yi-Ching Chen et al., 2012), industri jasa seperti perhotelan dan pariwisata (D'Annunziohijau et al., 2002 dalam Ipekc \& Irmak, 2009 dan López-cabarcos, Pinho, \& Vázquez-rodríguez, 2014), rumah sakit (Mosadeghrad, Ferlie, \& Rosenberg, 2008), polisi (Crow et al., 2012 dan Spagnoli \& Caetano, 2012), dan bank (Sakina, 2008) (Abdulkadir, Isiaka, \& Adedoyin, 2012) (Abdallah, Obeidat, \& Aqqad, 2017).

Hilangnya komitmen karyawan di industri perbankan berarti organisasi akan kehilangan dukungan dan loyalitas dari karyawan (Sakina, 2008:54). Karyawan yang tidak komitmen akan cenderung tidak peduli dengan tujuan organisasi, cenderung melanggar aturan, dan kehilangan semangat dalam bekerja, maka komitmen terhadap organisasi sangat penting dan vital bagi kehidupan industri perbankan (Sakina, 2008:54).

Masalah komitmen organisasi terjadi juga pada Bank X salah satu bank konvensional Indonesia. Bank X merupakan salah satu perbankan terbesar di Indonesia yang senantiasa meningkatkan kinerja dan layanannya. Semakin pesatnya pertumbuhan bank tersebut harus didukung pula oleh komitmen karyawan pada organisasi. Hal ini perlu 
diperhatikan oleh pihak manajemen, karena seorang karyawan yang kurang komitmen terhadap organisasinya akan akan berdampak pada kurangnya tanggung jawab seseorang dalam menjalankan pekerjaannya sehingga menggangu tercapainya tujuan organisasi. Gambaran umum rendahnya komitmen organisasi Bank $\mathrm{X}$ dapat dilihat dari data turnover karyawan. Tingkat Turnover Karyawan Bank X Tahun 2015-2017 menunjukan bahwa tingkat turnover mengalami peningkatan selama 3 tahun terakhir, yaitu dari tahun 2015 menuju tahun 2016 mengalami kenaikan sebesar 13,95\% dan dari tahun 2016 menuju tahun 2017 mengalami kenaikan sebesar $16,00 \%$. Semakin tingginya komitmen organisasi akan berpengaruh terhadap penurunan turnover intentions dan sebaliknya jika komitmen organisasi semakin rendah, akan berdampak negatif ke perusahaan yaitu akan berpengaruh terhadap peningkatan turnover intentions yang berarti akan berdampak buruk ke perusahaan (Sutanto, 2013:87).

Lemahnya komitmen organisasi juga ditunjukkan dari data rekapitulasi kemangkiran dan keterlambatan karyawan Bank $\mathrm{X}$ yang cukup tinggi. Hal ini dapat menunjukkan bahwa masih rendahnya tingkat kedisiplinan karyawan Bank X, di mana pada tingkat ketidakhadiran tanpa keterangan pun masih di atas $10 \%$. Rendahnya kedisiplinan karyawan akan menghambat proses produksi perusahaan dan tingkat ketidakhadiran tersebut menunjukan masih rendahnya komitmen kerja karyawan terhadap perusahaan. Keterlambatan dan ketidakhadiran karyawan ini dapat menyebabkan adanya kelambanan dalam pekerjaan, tidak disiplin terhadap waktu, pekerjaan yang sudah ditargetkan akan tertunda dan hal ini berdampak pada komitmen karyawan Bank X.

Komitmen organisasi adalah suatu keadaan di mana seorang karyawan memihak organisasi tertentu serta tujuan-tujuan dan keinginannya untuk mempertahankan keanggotaan dalam organisasi tersebut (Robbins, S. P., \& Judge, 2012). Selanjutnya komitmen keanggotaan secara umum dapat didefinisikan sebagai tingkat keterlibatan psikologis anggota pada organisasi tertentu (Summers dan Acito, 2000 dalam Sutrisno,
2010:93). Komitmen kerja dapat didefinisikan sebagai derajat hubungan individu memandang dirinya sendiri dengan pekerjaannya dalam organisasi tertentu (Jewell dan Siegall, 1998 dalam Sutrisno, 2010:93). Berbagai definisi yang menjelaskan komitmen organisasi, komitmen organisasi adalah kuatnya pengenalan dan keterlibatan seseorang dalam suatu organisasi tertentu (Porter, et al., 1974 dalam Gangai \& Agrawal, 2015). Tiga dimensi dari komitmen organisasional yang diutarakan oleh Robbins, (2012) adalah: (1) komitmen afektif (affective commitment), (2) komitmen berkelanjutan (continuance commitment), dan (3) komitmen normatif (normative commitment).

Komitmen organisasi tersusun dari keterikatan individu secara psikologis kepada organisasi termasuk perasaan akan job involvement, loyalitas, dan keyakinan terhadap nilai organisasi (Staw 1995 dalam Angelia 2013). Komitmen karyawan kepada organisasi sebagai ikatan kewajiban individu terhadap organisasi yang mencakup job involvement, kesetiaan, dan perasaan percaya terhadap nilai-nilai organisasi (O'Reilly 1989 dalam Sopiah, 2008:156). Job involvement diartikan sebagai setiap anggota organisasi harus aktif berpartispasi dan mempunyai prinsip bahwa pekerjaan sebagai bagian paling penting dan signifikan dalam kehidupan dan mengenali kinerja sebagai fitur utama dari dirinya. (Kanungo, 1982 dalam Robbins, 2003). Keterlibatan pekerjaan adalah tingkatan di mana orang mengidentifikasi dengan pekerjaan mereka, secara aktif berpartisipasi di dalamnya dan menganggap kinerjanya penting untuk harga diri mereka (Saleh dan Hosek, 1976 dalam Ipekc \& Irmak, 2009). Job involvement merupakan derajat dimana seorang karyawan mengidentifikasikan pekerjaannya, secara aktif berpatisipasi didalamnya, dan menganggap performa kerjanya sebagai hal penting dalam menghargai dirinya (Robbins \& Coulter, 2010). Job involvement adalah mengukur tingkat yang mana orang-orang mengidentifikasi secara psikologi dengan pekerjaanya dan menganggap kinerja mereka yang dihargai penting untuk nilai diri (Robbins \& Judge, 2015). Job involvement meliputi 3 dimensi yang dikemukakan 
oleh Kanungo, 1982; Robbins, 2003 dalam Ansel \& Wijono (2012:130) yang meliputi: (1) aktif berpartisipasi dalam pekerjaan, (2) mengutamakan, dan (3) pekerjaan penting bagi harga diri, harga diri merupakan sikap dan kepercayaan diri dalam keterampilan, kemampuan dan hubungan sosial (Ferreira, 2016 dalam Widjajanta et al., 2018).

Lima faktor lain yang dapat memengaruhi komitmen karyawan pada organisasi, yaitu budaya keterbukaan, kepuasan kerja, kesempatan karyawan untuk berkembang, arah organisasi, dan penghargaan kerja yang sesuai dengan kebutuhan (Stum 1998, dalam Sopiah, 2008:164). Penelitian ini, penulis menggunakan dua faktor yang memengaruhi komitmen organisasi yaitu job involvement untuk melihat pengaruhnya terhadap komitmen organisasi. Kepuasan kerja adalah hasil dari persepsi karyawan tentang seberapa baik pekerjaan yang mereka lakukan (Luthans, 2011). Kepuasan kerja dapat menggambarkan perasaan dari karyawan, baik berupa perasaan positif ataupun negatif. Seseorang dengan tingkat kepuasan kerja yang tinggi memiliki perasaan positif tentang pekerjaannya, sementara seseorang yang tidak puas memiliki perasaan yang negatif tentang pekerjaan tersebut. Ketika individu membicarakan sikap karyawan, yang sering dimaksudkan adalah kepuasan kerja. (Robbins \& Judge, 2012). Perdapat lain menyatakan bahwa kepuasan kerja adalah suatu perasaan positif tentang pekerjaan yang dihasilkan dari suatu evaluasi dari karakteristik-karakteristiknya (Robbins \& Judge 2015). Lima dimensi yang telah diidentifikasi untuk mengukur kepuasan kerja, yakni: (1) the work itself (pekerjaan itu sendiri, (2) pay (gaji)., (3) promotion opportunities (peluang promosi), (4) supervision (pengawasan), dan (5) co-workers (rekan kerja) (luthans, 2011).

Rumusan masalah dalam penelitian ini adalah: (1) adakah pengaruh job involvement karyawan terhadap komitmen organisasi Bank X, (2) adakah pengaruh kepuasan kerja karyawan terhadap komitmen organisasi Bank X, dan (3) adakah pengaruh job involvement karyawan dan kepuasan kerja karyawan terhadap komitmen organisasi karyawan Bank X
Tujuan dilakukannya penelitian ini adalah: (1) untuk memperoleh temuan mengenai pengaruh job involvement karyawan terhadap komitmen organisasi karyawan Bank X, (2) untuk memperoleh temuan mengenai pengaruh kepuasan kerja karyawan terhadap komitmen organisasi karyawan Bank X, dan (3) untuk memperoleh temuan mengenai tingkat komitmen organisasi karyawan bank konvensional Indonesia memperoleh temuan mengenai pengaruh job involvement dan kepuasan kerja karyawan terhadap komitmen organisasi karyawan Bank X.

\section{METODE PENELITIAN}

Penelitian ini menganalisis pengaruh job involvement dan kepuasan kerja terhadap komitmen organisasi. Objek penelitian sebagai variabel bebas yaitu job involvement (X1) dengan dimensi aktif berpartisipasi dalam pekerjaan, mengutamakan pekerjaan, dan pekerjaan penting bagi harga diri. Kepuasan kerja (X2) memiliki dimensi yaitu pekerjaan itu sendiri (the work itselft), gaji (pay), peluang promosi (promotion opportunities), pengawasan (supervision), dan rekan kerja (co-workers). Masalah penelitian yang merupakan variabel terikat yaitu komitmen organisasi (Y) yang terdiri dari dimensi komitmen afektif (affective commitment), komitmen keberlanjutan (continuance commitment) dan komitmen normatif (normative commitment).

Penelitian ini dilakukan di Bank X yaitu salah satu bank konvensional Indonesia, terhadap 54 karyawan. Penelitian ini dilaksanakan bulan MeiSeptember 2018. Metode penelitian yang digunakan yaitu cross sectional method dengan jenis penelitian verifikatif. Berdasarkan jenis penelitian tersebut, maka metode yang digunakan dalam penelitian ini adalah explanatory survey yang bertujuan untuk menguji hipotesis antara variabel satu dengan variabel lain. Teknik pengumpulan data yang digunakan adalah studi pustaka dan kuesioner (angket). Teknik analisis data yang digunakan yaitu Partial Least Squares (PLS) untuk menjelaskan ada atau tidaknya hubungan antar variabel laten, dengan alat bantu software komputer program smartPLS versi 3.0. 


\section{HASIL DAN PEMBAHASAN}

Pengujian ini dilakukan untuk melihat pengaruh job involvement dan kepuasan kerja terhadap komitmen organisasi. Untuk menguji kebenaran mengenai pengaruh job involvement dan kepuasan kerja terhadap komitmen organisasi, maka akan dilakukan perhitungan dengan analisis PLS (Partial Least Squares) dengan bantuan software SmartPLS 3.0.

\section{Evaluasi Model Pengukuran (Outer Model)}

Model pengukuran (Outer Model) merupakan model yang menghubungkan antara variabel laten dengan variabel manifes. Analisa outer model dilakukan untuk menguji validitas konstruk dan reliabilitas instrumen penelitian. Penelitian ini terdapat 3 variabel laten dengan 11 variabel manifes. Variabel laten job involvement terdiri dari 3 variabel manifes, kepuasan kerja terdiri dari 5 variabel manifes dan komitmen organisasi terdiri dari 3 variabel manifes.

Tiga kriteria untuk menilai outer model yaitu Convergent Validity, Discriminant Validity, dan Composite Reability. Validitas konstruk menunjukan seberapa baik hasil yang diperoleh dari suatu mengukuran sesuai teori-teori yang digunakan untuk mendefinisikan suatu konstruk (Abdillah, 2015:195). Korelasi yang kuat antara kontruk dengan item-item pertanyaannya dan hubungan yang lemah dengan variabel lainnya merupakan salah saru cara menguji validitas konstruk. Validitas konstruk terdiri dari validitas konvergen dan validitas diskriminan. Sedangkan uji reliabilitas suatu konstruk dilakukan untuk membuktikan akurasi konsistensi dan ketepatan instrumen dalam mengukur konstruk.

\section{Uji Validitas Konvergen (Convergent Validity)}

Convergent validity digunakan untuk mengukur seberapa besar indikator yang ada dapat menerangkan variabel latennya artinya semakin besar convergent validity maka semakin besar kemampuan indikator tersebut dalam menerapkan variable latennya.
Tabel 1. Nilai Outer Loading

\begin{tabular}{|c|c|c|c|c|}
\hline & $\begin{array}{c}\text { Original } \\
\text { Sample } \\
\text { (O) }\end{array}$ & $\begin{array}{c}\text { Sample } \\
\text { Mean } \\
\text { (M) }\end{array}$ & $\begin{array}{l}\text { Standard } \\
\text { Deviation } \\
\text { (STDEV) }\end{array}$ & $\begin{array}{c}\text { T Statistics } \\
\text { (|O/STDEV } \mid)\end{array}$ \\
\hline $\begin{array}{l}\text { JI1 <- } \\
\text { JI }\end{array}$ & 0.833 & 0.835 & 0.056 & 14.894 \\
\hline $\begin{array}{l}\text { JI2 }<- \\
\text { JI }\end{array}$ & 0.752 & 0.737 & 0.098 & 7.648 \\
\hline $\begin{array}{l}\text { JI3 <- } \\
\text { JI }\end{array}$ & 0.905 & 0.907 & 0.024 & 38.242 \\
\hline $\begin{array}{l}\text { KK1 }<- \\
\text { KK }\end{array}$ & 0.797 & 0.787 & 0.089 & 8.947 \\
\hline $\begin{array}{l}\text { KK2 <- } \\
\text { KK }\end{array}$ & 0.758 & 0.742 & 0.091 & 8.299 \\
\hline $\begin{array}{l}\text { KK3 <- } \\
\text { KK }\end{array}$ & 0.775 & 0.755 & 0.082 & 9.459 \\
\hline $\begin{array}{l}\text { KK4 <- } \\
\text { KK }\end{array}$ & 0.730 & 0.734 & 0.092 & 7.923 \\
\hline $\begin{array}{l}\text { KK5 <- } \\
\text { KK }\end{array}$ & 0.726 & 0.720 & 0.091 & 8.007 \\
\hline $\begin{array}{l}\text { KO1 <- } \\
\text { KO }\end{array}$ & 0.867 & 0.866 & 0.047 & 18.636 \\
\hline $\begin{array}{l}\text { KO2 <- } \\
\text { KO }\end{array}$ & 0.868 & 0.861 & 0.048 & 18.101 \\
\hline $\begin{array}{l}\text { KO3 <- } \\
\text { KO }\end{array}$ & 0.708 & 0.690 & 0.127 & 5.583 \\
\hline
\end{tabular}

Berdasarkan Tabel 1. Nilai Outer Loading, semua indikator dari masing-masing variabel job involvement, kepuasan kerja, dan komitmen organisasi memiliki Loading Factor diatas 0,5 sehinggga diketahui bahwa semua indikator job involvement, kepuasan kerja, dan komitmen organisasi valid sebagai indikator untuk mengukur konstrak/variabel masing-masing.

\section{Uji Validitas Diskriminan (Discriminant Validity)}

Evaluasi discriminant validity dimulai dengan melihat cross loading. Nilai cross loading menunjukan besarnya korelasi antara setiap variabel laten dengan indikatornya dan indikator dengan variabel laten lainnya.

Tabel 2. Cross Loading

\begin{tabular}{lccc}
\hline & $\begin{array}{l}\text { Job } \\
\text { Involvemen } \\
\boldsymbol{t} \text { (X1) }\end{array}$ & $\begin{array}{l}\text { Kepuasa } \\
\text { n Kerja } \\
(\mathbf{X 2})\end{array}$ & $\begin{array}{l}\text { Komitmen } \\
\text { Organissas } \\
\mathbf{i}(\mathbf{Y})\end{array}$ \\
\hline J11 & 0.833 & 0.606 & 0.536 \\
J12 & 0.752 & 0.514 & 0.406 \\
J13 & 0.905 & 0.688 & 0.662 \\
\hline
\end{tabular}


A.P. Sari, S.H. Senen \& M. Masharyono.,

Studi Komitmen Organisasi Karyawan Bank X: Peran Job Involvement Dan Kepuasan Kerja / 12

\begin{tabular}{lccc}
\hline & $\begin{array}{l}\text { Job } \\
\text { Involvemen } \\
\boldsymbol{t}(\mathbf{X 1})\end{array}$ & $\begin{array}{l}\text { Kepuasa } \\
\text { n Kerja } \\
(\mathbf{X 2})\end{array}$ & $\begin{array}{l}\text { Komitmen } \\
\text { Organissas } \\
\mathbf{i}(\mathbf{Y})\end{array}$ \\
\hline KK1 & 0.726 & 0.797 & 0.610 \\
KK2 & 0.463 & 0.758 & 0.533 \\
KK3 & 0.551 & 0.775 & 0.555 \\
KK4 & 0.477 & 0.730 & 0.508 \\
KK5 & 0.532 & 0.726 & 0.477 \\
KO1 & 0.622 & 0.671 & 0.867 \\
KO2 & 0.502 & 0.591 & 0.868 \\
KO3 & 0.479 & 0.460 & 0.708 \\
\hline
\end{tabular}

Berdasarkan Tabel 2. Cross Loading diketahui bahwa indikator JI1-JI3 lebih tinggi berkorelasi dengan variabel job involvement (X1) dibandingkan dengan variabel lainnya. Hal tersebut juga terjadi pada indikator KK1-KK5 yang lebih tinggi berkorelasi dengan variabel kepuasan kerja (X2) dibanding dibandingkan dengan variabel lainnya. Indikator KO1-KO3 yang lebih tinggi berkorelasi dengan variabel komitmen organisasi (X2) dibanding dibandingkan dengan variabel lainnya. Nilai cross loading indikator yang lebih tinggi terhadap variabelnya dibandingkan dengan variabel lain menunjukan bahwa discriminant validity dalam penelitian ini sudah sesuai.

\section{Uji Composite Reliability}

Uji reliabilitas konstruk dilakukan untuk membuktikan akurasi, konsistensi, dan ketepatan instrumen dalam mengukur konstruk. Penggunakan cronbabach alpa untuk mengujhi reliabilitas akan memberikan nilai yang lebih rendah sehingga disarankan untuk menggunakan composite reliability dalam menguji reliabilitas suatu konstruk. Nilai composite reliability harus lebih besar dari 0,70 untuk penelitian confirmatory dan nilai 0,60 - 0,70 masih dapat diterima untuk penelitian yang bersifat exploratory (Ghozali, 2014:75). Berikut adalah nilai composite reliability.
Tabel 3. Nilai Composite Reliability dan Cronbach's Alpha

\begin{tabular}{lcc}
\hline & $\begin{array}{c}\text { Composite } \\
\text { Reliability }\end{array}$ & $\begin{array}{l}\text { Cronbach's } \\
\text { Alpha }\end{array}$ \\
\hline $\begin{array}{l}\text { Job Involvement } \\
\text { (X1) }\end{array}$ & 0.871 & 0.780 \\
$\begin{array}{l}\text { Kepuasan Kerja } \\
\text { (X2) }\end{array}$ & 0.871 & 0.815 \\
$\begin{array}{l}\text { Komitmen } \\
\text { Organisasi (Y) }\end{array}$ & 0.857 & 0.750 \\
\hline
\end{tabular}

Berdasarkan pada Tabel 3. Nilai Composite Reliability dan Cronbach's Alpha hasil composite reliability untuk masing-masing variabel diatas 0,7. Hal ini, menunjukan bahwa seluruh indikator dari masing-masing variabel involvement, kepuasan kerja, dan komitmen organisasi dapat dikatakan variabel tersebut memilki reliabilitas atau keterandalan yang baik sebagai alat ukur.

\section{Evaluasi Struktural Model (Inner Model) R-Square}

Setelah dilakukan evaluasi outer model, selanjutnya dilakukan pengujian model struktural atau inner model yang dilakukan dengan melihat $\mathrm{R}$-square pada konstruk endogen yang merupakan uji goodness-fitmodel. Konstruk endogen dalam penelitian ini adalah komitmen organisasi (Y). Berikut adalah nilai R-square.

Tabel 3. Nilai Composite Reliability dan Cronbach's Alpha

\begin{tabular}{lc}
\hline & R Square \\
\hline $\begin{array}{l}\text { Komitmen Organisasi } \\
(Y)\end{array}$ & 0.547 \\
\hline
\end{tabular}

Berdasarkan Tabel 3. Nilai Composite Reliability dan Cronbach's Alpha nilai $\mathrm{R}^{2}$ konstruk endogen komitmen organisasi (Y) pada model penelitian termasuk pada kategori moderate yaitu sebesar 0,547. Nilai tersebut mempunyai pengertian bahwa komitmen organisasi dijelaskan oleh konstruk job involvement dan kepuasan kerja sebesar 54,7\% dan sisanya dijelaskan oleh variabel lain diluar model.

\section{Relevansi Prediksi $\left(\mathbf{Q}^{2}\right)$}

Stone Geisser's $\mathrm{Q}^{2}$ dipergunakan untuk melihat pengaruh relatif model struktural terhadap 
pengukuran observasi untuk variabel laten endogen. The Stene-Geiser kriteria mengajukan bahwa suatu model harus mampu memprediksi indikator variabel laten endogen (Hanseler et al., 2009). Teknik ini dapat merepresentasikan syntehesis dari cross validation dan fungsi fitting dengan prediksi dari observed variabel dan estimasi dari parameter konstruk. Pendekatan ini diadaptasi PLS dengan menggunakan prosedur blindfolding. Berikut adalah nilai relevansi prediksi $\left(\mathrm{Q}^{2}\right)$.

Tabel 4. Hasil Relevansi Prediksi $\left(Q^{2}\right)$

\begin{tabular}{lcc}
\hline \multicolumn{1}{c}{ Konstruk } & $\mathbf{Q}^{\mathbf{2}}$ & Keterangan \\
\hline $\begin{array}{l}\text { Komitmen } \\
\text { Organisasi }(\mathrm{Y})\end{array}$ & 0.321 & $>0$ \\
\hline
\end{tabular}

Berdasarkan pada Tabel 4. Hasil Relevansi Prediksi $\left(\mathrm{Q}^{2}\right)$ nilai konstruk blindfolding menunjukan nilai $\mathrm{Q}^{2}>0$ hai ini memberikan pengertian bahwa nilai variabel endogen komitmen organisasi (Y) sudah direkonstruksi dengan baik dengan demikian model penelitian mempunyai relevansi prediktif.

\section{Effect Size $\left(\mathbf{f}^{2}\right)$}

Perubahan nilai $\mathrm{R}^{2}$ dapat digunakan untuk melihat apakah pengukuran variabel laten eksogen terhadap variabel latenendogen meiliki pengaruh yang substansif. Halini dapat diukur dengan effect size $\mathrm{f}^{2}$. Kriteria peneliai effect size $\mathrm{f}^{2}$ adalah 0,02 (kecil), 0,15 (sedang), dan 0,35 (besar). Berikut adalah nilai effect size $\mathrm{f}^{2}$.

Tabel 5. Hasil Effect Size $\left(\mathbf{f}^{2}\right)$

\begin{tabular}{lll}
\hline \multicolumn{1}{c}{ Variabel } & $\begin{array}{c}\text { Effect } \\
\text { Size }\end{array}$ & \multicolumn{1}{c}{ Kriteria } \\
\hline $\begin{array}{l}\text { Job Involvement } \\
\text { (X1) }\end{array}$ & 0.091 & Kecil \\
$\begin{array}{l}\text { Kepuasan Kerja } \\
(\mathrm{X} 2)\end{array}$ & 0.250 & Sedang \\
\hline
\end{tabular}

Berdasarkan Tabel 5. Hasil Effect Size (f²) pengaruh job involvement (X1) memberikan efek kecil $(0,091)$ sedangkan kepuasan kerja (X2) memberikan efek sedang $(0,250)$ pada komitmen organisasi (Y).

\section{Goodness of Fit (GoF)}

Untuk memvalidasi model seracar keseluruhan, digunakan Goodness of Fit (GoF) yang diperkenalkan oleh Tenenhaus et. al. (2004) dengan sebutan GoF Index. Sebagai ukuran tunggal untuk memvalidasi performa gabungan diantara model pengukuran dan model struktural, yang diperoleh dari average communalities index dikalikan dengan nilai averange $\mathrm{R}^{2}$. Dari perhitungan GoF dalam penelitian ini adalah :

$$
\begin{gathered}
G o F=\sqrt{\overline{C o m} \times \overline{R^{2}}} \\
\text { GoF }=\sqrt{0.645 \times 0.547} \\
G o F=\sqrt{0.353} \\
G o F=0.594
\end{gathered}
$$

Dengan hasil GoF 0,594 maka dapat diinterprestasikan hawa model dalam penelitian ini termasuk dalam nilai GoF besar karena nilainya melebihi 0,36. Hal ini memberikan pengertian bahwa validasi pengukuran model prediksi secara keseluruhan pada penelitian ini cukup besar.

\section{Pengujian Hipotesis Pengujian Outer Model}

Pengujian hasil outer atau hubungan dari variabel laten menuju ke indikator-indikatornya dapat dilihat pada Tabel 1. Nilai Outer Loading. Nilai t-hitung dari variabel laten kesemua indikatornya didapat melalui bootstrapping, sehingga didapat nilai output outer loading. Dalam tabel outer loading didapat nilai t-statistik lebih besar dari t tabel $(1,96)$. Dari hasil outer loading dapat disimpulkan bahwa semua indikator konstruk dalam model valid karena t-statistik yang dihasilkan lebih besar dari 1,96.

\section{Pengujian Inner Model}

Pengujian hipotesis inner model adalah pengujian antar konstruk yang ditunjukan dari hasil inner model atau hubungan antar konstruk. Pengujian ini dilakukan dengan cara two tail pada $\alpha=0,05 \mathrm{t}_{\mathrm{tab}}=1,96$ kemudian dibandingkan dengan $\mathrm{t}-$ statistik pada path coefficient hasil bootstrapping. 
Tabel 6. Output Inner Weight

\begin{tabular}{lccccc}
\hline & $\begin{array}{c}\text { Original } \\
\text { Sample } \\
(\mathbf{O})\end{array}$ & $\begin{array}{c}\text { Sample } \\
\text { Mean } \\
(\mathbf{M})\end{array}$ & $\begin{array}{c}\text { Standard } \\
\text { Deviation } \\
\text { (STDEV) }\end{array}$ & $\begin{array}{c}\text { T } \\
\text { Statistics }\end{array}$ & Ket \\
\hline X1 -> & 0.297 & 0.314 & 0.141 & 2.102 & Sig \\
Y & & & & & Sig \\
X2 -> & 0.494 & 0.480 & 0.155 & 3.184 & \\
$\begin{array}{l}\text { Y } \\
\text { X1 \& }\end{array}$ & & & & & Sig \\
X2 - & 0.547 & 0.565 & 0.112 & 4.877 & \\
$>$ Y & & & & & \\
\hline
\end{tabular}

Berdasarkan hasil inner model pada Tabel 6. Output Inner Weight dapat dideskripsikan hasil pengujian hipotesis dalam penelitian sebagai berikut:

\section{Pengujian Hipotesis 1}

H1 : terdapat pengaruh positif dari job involvement karyawan (X1) terhadap komitmen organisasi (Y)

Dari hasil pengolahan data Tabel 6 hipotesis penelitian penyatakan bahwa job involvement karyawan (X1) berpengaruh positif terhadap komitmen organisasi (Y). Hasil uji terhadap koefisien parameter antara job involvement (X1) dan komitmen organisasi (Y) menujukan adannya pengaruh positif sebesar $29,7 \%$ dengan nilai tstatistik 2,102 dan signifikan pada $\alpha=0,05$, dapat disimpulkan bahwa job involvement berpengaruh positif terhadap komitmen organisasi (2,102>1.96), dengan demikian H1 diterima.

Berdasarkan hasil penelitian yang bersifat empiris yaitu pengaruh job involvement terhadap komitmen organisasi. Komitmen organisasi dipengaruhi oleh job involvement. Adapun besarnya pengaruh job involvement karyawan terhadap komitmen organisasi sebesar 29,7\% yang menurut Guilford hasil ini berada pada kategori rendah. Hal ini berarti antara job involvement karyawan memiliki pengaruh signifikan/positif terhadap komitmen organisasi. Hal ini sesuai dengan penelitian yang dilakukan oleh Liwun \& Prabowo (2015:35) bahwa terdapat pengaruh positif dan signifikan antara job involvement dengan komitmen organisasi sebesar 47,7\%. Hal ini mengindikasikan bahwa semakin tinggi job involvement dari seorang karyawan maka semakin tinggi pula komitmen organisasi tersebut. Job involvement juga dapat meningkatkan hubungan antara karyawan dengan pekerjaannya. Hal ini disebabkan oleh karyawan tersebut menikmati pekerjaan yang sedang dilakukannya saat ini. Hasil penelitian Khan, Jam, Akbar, Khan, \& Hijazi (2011) juga memperoleh hasil yang sama yaitu job involvement berpengaruh positf dan signifikan terhadap komitmen organisasi. Hasil tersebut memiliki arti semakin tinggi job involvement yang dirasakan oleh karyawan maka semakin kuat persepsi karyawan terhadap komitmen organisasional.

\section{Pengujian Hipotesis 2}

$\mathrm{H} 2$ : terdapat pengaruh positif dari kepuasan kerja karyawan (X2) terhadap komitmen organisasi (Y)

Dari hasil pengolahan data Tabel 6 hipotesis penelitian penyatakan bahwa kepuasan kerja karyawan (X2) berpengaruh positif terhadap komitmen organisasi (Y). Hasil uji terhadap koefisien parameter antara kepuasan kerja (X2) dan komitmen organisasi (Y) menujukan adannya pengaruh positif sebesar $49,9 \%$ dengan nilai tstatistik 3,184 dan signifikan pada $\alpha=0,05$, dapat disimpulkan bahwa kepuasan kerja berpengaruh positif terhadap komitmen organisasi (3,184>1.96), dengan demikian $\mathrm{H} 2$ diterima.

Berdasarkan hasil penenlitian yang bersifat empiris yaitu pengaruh kepuasan kerja terhadap komitmen organisasi. Komitmen organisasi dipengaruhi oleh kepuasan kerja. Adapun besarnya pengaruh kepuasan kerja karyawan terhadap komitmen organisasi sebesar $49,4 \%$ yang menurut Guilford hasil ini berada pada kategori sedang. Hal ini berarti antara kepuasan kerja karyawan memiliki pengaruh signifikan/positif terhadap komitmen organisasi. Hal ini sesuai dengan hasil penelitian yang dilakukan Lestari \& Sambul (2016:5) menyatakan bahwa kepuasan kerja berpengaruh positif dan signifikan terhadap komitmen organisasional karyawan. Hasil penelitian ini menunjukkan bahwa jika terjadi peningkatan pada kepuasan kerja, maka komitmen 
organisasional juga akan meningkat. Kepuasan akan gaji, kepuasan akan rekan kerja, supervisor dan pekerjaan itu sendiri yang merupakan bagian daripada dimensi kepuasan kerja, dibutuhkan oleh para pekerja untuk memenuhi kebutuhan dasar mereka. Ketika kebutuhan mereka terpenuhi maka tingkat komitmen organisasional mereka akan menjadi tinggi. Hasil penelitian yang dilakukan oleh Hidayati \& Rahmawati (2015:13) menyatakan bahwa kepuasan kerja berpengaruh positif dan signifikan terhadap komitmen organisasi sebesar $81,4 \%$. Hal ini memberikan makna bahwa kepuasan kerja yang dirasakan karyawan telah memberikan konskuensi positif berupa semakin meningkatnya komitmen organisasi yang terdiri dari komitmen afektif, komitmen keberlanjutan dan komitmen normatif secara nyata.

\section{Pengujian Hipotesis 3}

H3 : terdapat pengaruh positif dari job involvement (X1) dan kepuasan kerja karyawan (X2) terhadap komitmen organisasi (Y)

Dari hasil pengolahan data Tabel 6 hipotesis penelitian penyatakan bahwa job involvement (X1) dan kepuasan kerja karyawan (X2) berpengaruh positif terhadap komitmen organisasi (Y). Hasil uji terhadap koefisien parameter antara job involvement (X1) dan kepuasan kerja (X2) dan komitmen organisasi (Y) menunjukan adannya pengaruh positif sebesar $54,7 \%$ dengan nilai tstatistik 4,877 dan signifikan pada $\alpha=0,05$, dapat disimpulkan bahwa job involvement dan kepuasan kerja berpengaruh positif terhadap komitmen organisasi $(4,877>1.96)$, dengan demikian H3 diterima. Output pemgujian model akhir penelitian dapat dilihat pada Gambar 1 berikut.

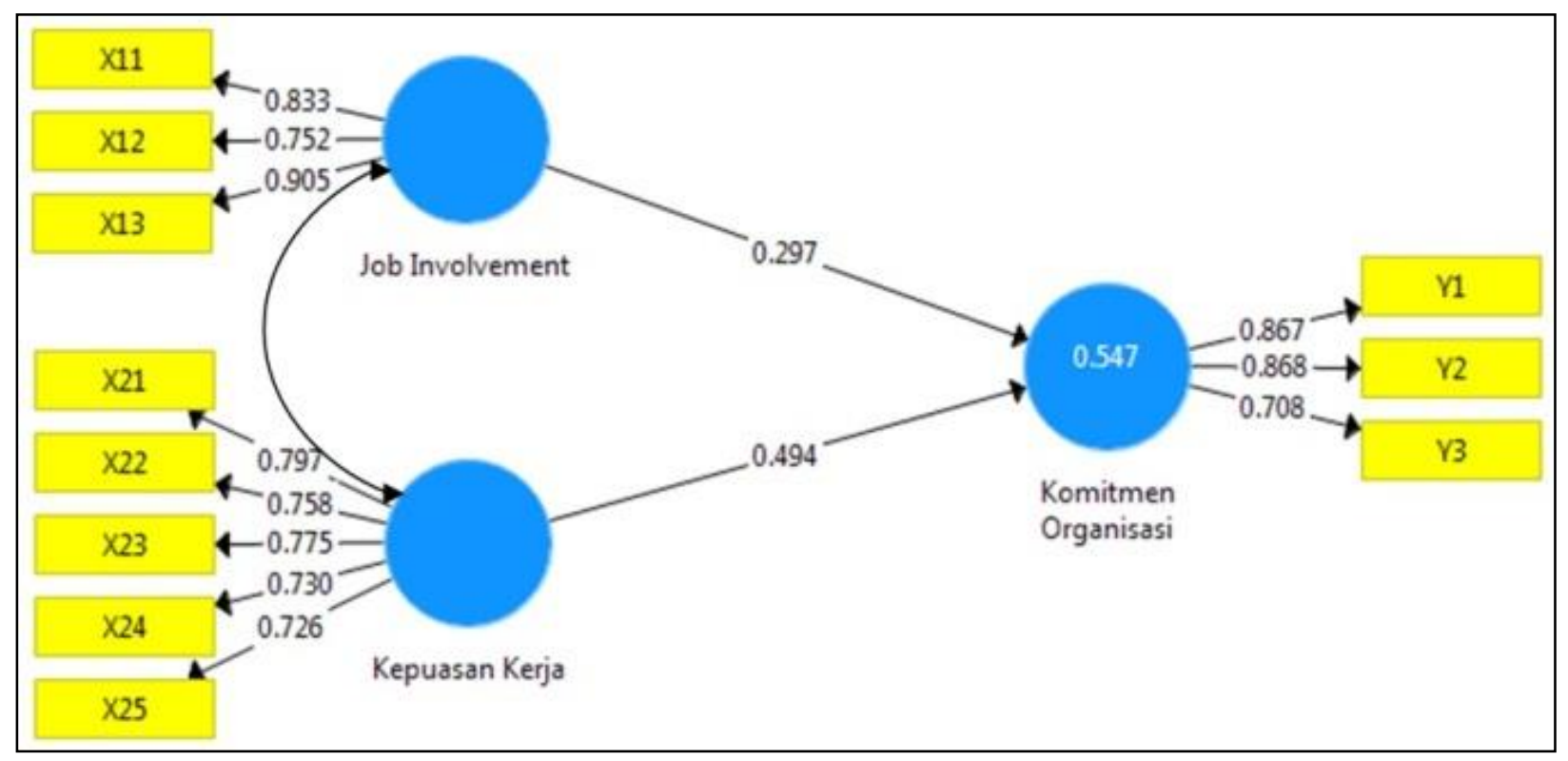

Gambar 1. Tampilan Output Pengujian Model Struktural

Berdasarkan hasil penenlitian yang bersifat empiris yaitu pengaruh job involvement dan kepuasan kerja karyawan terhadap komitmen organisasi. Komitmen organisasi dipengaruhi oleh job involvement dan kepuasan kerja karyawan. Adapun besarnya pengaruh job involvement dan kepuasan kerja karyawan terhadap komitmen organisasi sebesar 54,7\% yang menurut Guilford hasil ini berada pada kategori sedang. Hal ini berarti antara job involvement dan kepuasan kerja karyawan memiliki pengaruh signifikan/positif terhadap komitmen organisasi. Hal tersebut dibuktikan juga oleh penelitian Ansel \& Wijono (2012:137) menyatakan faktor yang mempengaruhi komitmen organisasi yaitu job involvement dan kepuasan kerja. Berdasarkan 
penelitian yang oleh Ansel \& Wijono (2012:137) menunjukan bahwa terdapat pengaruh yang positif signifikan keterlibatan kerja dan kepuasan kerja terhadap komitmen organisasi. Keterlibatan kerja merupakan faktor internal dan kepuasan kerja merupakan faktor internal dan eksternal yang perlu ditumbuhkan dalam diri setiap karyawan. Kedua faktor internal dan eksternal ini dapat digunakan untuk meningkatkan komitmen karyawan terhadap organisasi. Sebagaimana Kuntjoro (2002) dalam Ansel \& Wijono (2012:137) mengatakan komitmen terhadap organisasi sangat penting sebagai salah satu syarat untuk memegang suatu jabatan yang ditawarkan dalam pekerjaan. Komitmen organisasi yang tinggi akan sangat menguntungkan untuk keberhasilan suatu organisasi.

\section{KESIMPULAN DAN SARAN}

Berdasarkan hasil penelitian yang telah dilakukan menggunakan analisis verifikatif, dapat diambil kesimpulan bahwa job involvement karyawan berpengaruh terhadap komitmen organisasi menunjukan adannya pengaruh positif sebesar 29,7\% menurut Guilford hasil ini berada pada kategori rendah. Hal ini menunjukkan bahwa semakin tinggi job involvement karyawan, maka semakin tinggi juga komitmen organisasi karyawan Bank X. Hasil penelitian menunjukan bahwa kepuasan kerja karyawan berpengaruh terhadap komitmen organisasi, menunjukan adannya pengaruh positif sebesar $49,9 \%$, menurut Guilford hasil ini berada pada kategori sedang. Hal ini menunjukkan bahwa semakin tinggi kepuasan kerja karyawan, maka semakin tinggi juga komitmen organisasi karyawan Bank X. Berdasarkan hasil penelitian menyatakan bahwa job involvement dan kepuasan kerja karyawan berpengaruh terhadap komitmen organisasi, menunjukan adannya pengaruh positif sebesar $54,7 \%$ menurut Guilford hasil ini berada pada kategori sedang. Hal ini menunjukkan bahwa semakin tinggi job involvement dan kepuasan kerja karyawan secara bersama-sama, maka semakin tinggi juga komitmen organisasi karyawan Bank X. Adanya penelitian ini diharapkan dapat membantu peneliti berikutnya dalam melakukan penelitian mengenai job involvement, kepuasan kerja dan komitmen organisasi dengan menggunakan indikator yang berbeda dari sumber teori yang lebih beragam, dan terhadap objek yang berbeda, karena masih banyaknya keterbatasan dalam penelitian ini, khususnya yang terkait dengan metode penelitian dan teknik pengumpulan data.

\section{DAFTAR PUSTAKA}

Abdallah, A. B., Obeidat, B. Y., \& Aqqad, N. O. (2017). An Integrated Model Of Job Involvement , Job Satisfaction And Organizational Commitment: A Structural Analysis In Jordan ' S Banking Sector, (January).

Http://Doi.Org/10.4236/Cn.2017.91002

Abdulkadir, D. S., Isiaka, S. B., \& Adedoyin, S. I. (2012). Effects Of Strategic Performance Appraisal, Career Planning And Employee Participation On Organizational Commitment: An Empirical Study. International Business Research, 5(4), 124-133. Http://Doi.Org/10.5539/Ibr.V5n4p124

Allen, N. J., \& Meyer, J. P. (1996). Affective , Continuance, And Normative Commitment To The Organization: An Examination Of Construct Validity. Journal of Vocational Behavior, 276(49), 252-276.

Angelia, N. (2013). Hubungan Antara Kualitas Kehidupan Kerja Dengan Komitmen Organisasi Pada Karyawan Perusahaan Genteng Mutiara, (9).

Ansel, M. F., \& Wijono, S. (2012). Pengaruh Keterlibatan Kerja Dan Kepuasan Kerja Terhadap Komitmen Organisasi Polisi, 05(02), 125-142.

Crow, M. S., Lee, C., \& Joo, J. (2012). Organizational Justice And Organizational Commitment Among South Korean Police Officers. Policing: An International Journal Of Police Strategies \& Management, 35(2), 402-423.

Http://Doi.Org/10.1108/13639511211230156 
Gangai, K. N., \& Agrawal, R. (2015). Job Satisfaction And Organizational Commitment: Is It Important For Employee Performance, 5(4), 269-278.

Hidayati, T., \& Rahmawati. (2015). Pengaruh Kepuasan Kerja Terhadap Komitmen Organisasi Dan Kinerja Pegawai Serta Kinerja Layanan.

Ipekc, E., \& Irmak, S. (2009). Path Analysis Of Organizational Commitment, Job Involvement And Job Satisfaction In Turkish Hospitality Industry, $\quad 64(1), \quad$ 4-16. Http://Doi.Org/10.1108/16605370910948821

Keskes, I. (2014). Relationship Between Leadership Styles And Dimensions Of Employee Organizational Commitment: A Critical Review And Discussion Of Future Directions. Intangible Capital, 10(1), 26-51.

Khan, T. I., Jam, F. A., Akbar, A., Khan, M. B., \& Hijazi, S. T. (2011). Job Involvement As Predictor Of Employee Commitment : Evidence From Pakistan, 6(4), 252-262. Http://Doi.Org/10.5539/Ijbm.V6n4p252

Kyoo, B., \& Jeung, J. H. J. Y. C.-W. (2006). The Effects Of Core Self-Evaluations And Transformational Leadership On Organizational Commitment. Leadership \& Organization Development Journal, 33(6). Http://Doi.Org/Http://Dx.Doi.Org/10.1108/09 564230910978511

Lestari, A. W., \& Sambul, S. A. P. (2016). Pengaruh Kepuasan Kerja Terhadap Komitmen Organisasional Pt. Bank Mandiri (Persero) Tbkarea Manado, 1-6.

Liwun, S. B. B., \& Prabowo, H. (2015). Pengaruh Keterlibatan Kerja Dan Spiritualitas Kerja Terhadap Komitmen Organisasi, 32-40.

López-Cabarcos, M. Á., Pinho, A. I. M., \& Vázquez-Rodríguez, P. (2014). The Influence Of Organizational Justice And Job Satisfaction On Organizational Commitment In Portugal's Hotel Industry. Cornell Hospitality Quarterly. Http://Doi.Org/10.1177/1938965514545680
Luthans, F. (2011). Organizational Behavior. New York: Mcgraw-Hill.

Mariyanti, E. (2014). Pengaruh Keterlibatan Kerja Dan Kepuasan Kerja Terhadap Komitmen Organisasi (Studi Kasus Pada Perawat Rumah Sakit Swasta Di Kota Padang), 1(1), 38-45.

Masharyono. (2015). Pengaruh Job Characteristics Terhadap Semangat Kerja Pegawai (Survey Pada Pegawai Pns Di Lingkungan Disparbud Jabar). Jurnal Riset Akuntansi Dan Keuangan, 3(3), 813-830.

Masharyono, \& Senen, S. H. (2015). Analisis Job Performance Pegawai Honorer Administrasi Dengan Kompetensi Dan Job Characteristics Dalam Mendukung Universitas Pendidikan Indonesia Mencapai Leading And Outstanding, 120-137.

Meyer, J. P., Allen, N. J., \& Smith, C. A. (1993). Commitment To Organizations And Occupations: Extension And Test Of A ThreeComponent Conceptualization. Journal of Applied Psychology, 78(4), 538-551.

Meyer, J. P., Paunonen, S. V, Gellatly, I. R., Goffin, R. D., \& Jackson, D. N. (1989). Organizational Commitment And Job Performance: It $\mathrm{S}$ The Nature of The Commitment That Counts. Journal Of Applied Psychology, 74(I), 152-156.

Mosadeghrad, A. M., Ferlie, E., \& Rosenberg, D. (2008). A Study Of The Relationship Between Job Satisfaction, Organizational Commitment And Turnover Intention Among Hospital Employees. Health Services Management Research, 21(March 2016), 211-227. Http://Doi.Org/10.1258/Hsmr.2007.007015

Neininger, A., Lehmann-Willenbrock, N., Kauffeld, S., \& Henschel, A. (2010). Effects Of Team And Organizational Commitment - A Longitudinal Study. Journal of Vocational Behavior, 76(3), 567-569. Http://Doi.Org/10.1016/J.Jvb.2010.01.009

Robbins, \& Coulter. (2010). Manajemen (Edisi Kese). Jakarta: Erlangga. 
Robbins, S. P., \& Judge, T. A. (2012). Organizational Behavior (12th Ed.). Boston: Pearson.

Robbins, S. P. (2003). Perilaku Organisasi,Jilid 2. Jakarta: Pt. Indeks Kelompok Gramedia.

Robbins, S. P., \& Judge, T. A. (2012). Perilaku Organisasi. Jakarta: Salemba Empat.

Robbins, S. P., \& Judge, T. A. (2015a). Organizational Behavior (16th Ed.). Boston: Pearson.

Robbins, S. P., \& Judge, T. A. (2015b). Perilaku Organisasi. Jakarta: Salemba Empat.

Sakina, N. (2008). Komitmen Organisasi Karyawan Pada Pt.Bank "X” Di Jakarta.

Senen, S. H. (2016). Pengaruh Lingkungan Dan Kemampuan Kerja Terhadap Kinerja Karyawan Pt. Ronadamar Sejahtera Cabang Bandung, 1(2), 47-55.

Senen, S. H., Sumiyati, \& Masharyono. (2016). The Effect Of Skill Variety, Task Identity, Task Significance, Autonomy And Feedback On Job Performance, 15, 585-588.

Senen, S. H., Sumiyati, \& Masharyono. (2017). Employee Performance Assessment System Design Based On Competence, 2, 68-70.

Sopiah. (2008). Perilaku Organisasi. Yogyakarta: Andi.

Spagnoli, P., \& Caetano, A. (2012). Personality And Organisational Commitment: The Mediating Role Of Job Satisfaction During Socialisation. Career Development International, $\quad$ 17(3), 255-275. Http://Doi.Org/10.1108/13620431211241081

Sutanto, E. M. (2013). Kepuasan Kerja, Komitmen Organisasional Dan Turnover Intentions. Jurnal Mitra Ekonomi Dan Manajemen Bisnis, 4(1), 76-88.

Sutrisno, E. (2010). Budaya Organisasi. Jakarta: Prenadamedia Group.
Widjajanta, B., Senen, S. H., Masharyono, Lisnawati, \& Anggraeni, C. P. (2018). The Impact Of Social Media Usage And SelfEsteem On Conspicuous Consumption: Instagram User Of Hijabers Community Bandung Member. International Journal Of Ebusiness And Egovernment Studies, 10(2), 113.

Yi-Ching Chen, M., Shui Wang, Y., \& Sun, V. (2012). Intellectual Capital And Organizational Commitment. Personnel Review, 41(3), 321-339. Http://Doi.Org/10.1108/00483481211212968 